\section{The impact of smoking on infertility, pregnancy outcomes and fetal development}

\author{
Mohammed Hamad, ${ }^{1}$ Khaled Refaat, ${ }^{2}$ \\ Constanze Fischer-Hammadeh, ${ }^{3}$ \\ Mohamad Eid Hammadeh ${ }^{3}$ \\ ${ }^{1}$ Faculty of Pharmacy and Medical \\ Sciences, Petra University, Amman \\ Jordan; ' Department of Obstetrics and \\ Gynecology, Al Azhar University, Egypt; \\ ${ }^{3}$ Department of Obstetrics and \\ Gynecology, University of Saarland, \\ Homburg-Saar, Germany
}

\section{Abstract}

Maternal smoking during pregnancy is one of the main causes of pregnancy complications and is correlated with poorer outcomes compared to pregnancy without smoking. Maternal smoking is associated with a statistically significant increase in the risks of placental abruption, placenta praevia, ectopic pregnancy and preterm pre-labor rupture of membranes. In addition, maternal smoking during pregnancy correlated with higher rates of low birth weight, perinatal mortality, and premature birth, as well as complications in respiratory, cardiovascular and nervous systems in childhood. Active and passive smoking of pregnant mothers seems to be one of the causative agents for these and other negative effects on both mothers and their infants. Physicians should clarify these hazardous effects to pregnant women and strongly advise them to quit smoking as soon as possible. Women who continue to smoke during pregnancy should be considered a high-risk pregnancy.

\section{Introduction}

Smoking is a worldwide problem and one third of the population are smokers. ${ }^{1}$ In addition, it was reported that exposure to the metabolites of tobacco smoke is correlated with cancer in the adult and in utero teratogenicity. ${ }^{2}$ Also, smoking during pregnancy is recognized as the most important preventable risk factor for an unsuccessful pregnancy outcome.

The report of the World Health Organization (WHO) indicates that smoking rates for women ( $\geq 15$-years of age) range between 7 and $17 \%$ in South Africa, Central and South America, and Asia, while higher rates of female smoking ranging from 24 to $27 \%$ were reported in the US, Europe, and Australia. ${ }^{3}$
Many studies revealed that there is an adverse effect of smoking on pregnancy outcomes $^{4-6}$ These negative effects have an influence on the health of both the mothers and their infants. For instance, pregnant women who smoke may suffer from spontaneous abortion, ${ }^{6}$ placental abruption, ${ }^{7}$ placenta praevia, ${ }^{4}$ and ectopic pregnancy. ${ }^{8}$ Moreover, the children of mothers who smoke may face prenatal death, ${ }^{9}$ premature delivery, ${ }^{4}$ and low birth, weight. ${ }^{9}$ To summarize, smoking during pregnancy is an important risk factor for maternal and fetal outcomes.

Recent studies showed that smoking during pregnancy is associated with intrauterine fetal growth retardation as well as disturbances in postnatal growth and development. ${ }^{10-12}$

Pregnant women who smoke and their children may face higher levels of oxidative stress than non-smokers. ${ }^{13-16}$ A high level of lipid hydroperoxide was detected in both active and passive pregnant smokers. ${ }^{17-19}$ Also, an ethane level test of the breath of the newborn infants of smoking women revealed a high level of oxidative stress. ${ }^{20}$

In 2010, Westbrook et al. reported that perinatal environmental tobacco smoke (ETS) exposure of primates resulted in significantly increased oxidative stress in which mitochondrial dysfunction and damage were accompanied by a significant decrease in mitochondrial antioxidant capacity and mitochondrial copy number in vascular tissue. ${ }^{21}$

In addition, Chelchowska et al. ${ }^{22}$ studied the effect of smoking on antioxidant levels in pregnant smokers and their fetuses. They concluded that tobacco smoke enhances lipid peroxidation and depletes antioxidant potential in the plasma of pregnant women and umbilical cord blood. Therefore, smoking during pregnancy may stimulate free radical damage in the mother and her growing fetus. ${ }^{22}$

Furthermore, it was reported that each stage of reproductive function, folliculogenesis, steroidogenesis, embryo transport, endometrial receptivity, endometrial angiogenesis, uterine blood flow and uterine myometrium is a target for the components of cigarette smoke. ${ }^{23}$

The aim of this review is to focus on the impact of maternal smoking on fertility, pregnancy outcomes and fetal development.

\section{Constituents of tobacco}

Tobacco smoke is known to be toxic to humans. Tobacco smoke contains more than 4800 chemicals; they are either in gaseous or particulate phases. The majority are found in the particulate phase, namely tar. ${ }^{24}$ Tar contains 200 chemicals considered to be poisons and 60 as possible carcinogens (e.g. benzo $[a]$ pyrene, benzene, lead, and chlorinat-
Correspondence: Mohamad Eid Hammadeh, Department of Obstetrics and Gynecology, University of Saarland, Homburg-Saar, Germany. Tel. +49.684.116.281.17 - Fax: +49.684.116.280.61 E-mail.mehammadeh@yahoo.de

Key words: smoking, infertility, pregnancy, fetal development.

Received for publication: 20 September 2011. Revision received: 19 December 2011.

Accepted for publication: 30 January 2012.

This work is licensed under a Creative Commons Attribution 3.0 License (by-nc 3.0).

(C) Copyright M. Hamad et al., 2012

Licensee PAGEPress srl, Italy

Teratology Studies 2012; 2:e1

doi:10.4081/ts.2012.e1

ed dioxins and furans).,25 Besides this, other components of tobacco smoke, such as arsenic and 1,3-butadiene, negatively affect the reproductive system. Also, hydrogen cyanide and arsenic have adverse effects on the cardiovascular system, acrolein and acetaldehyde affect the respiratory system, and toluene and phenol affect the nervous system. ${ }^{2,25}$

In addition, cigarette smoke contains reactive oxygen species (ROS), such as oxygen oxides, alkyl radicals, peroxyl radicals and peroxynitrite, which may cause diseases. ${ }^{26}$ However, tobacco constituents vary according to the plant, the place where they are grown and the manufacturing process. ${ }^{27-28}$

Tobacco smoke is a complex mixture that contains substances such as polycyclic aromatic hydrocarbons (PAHs) and N-nitrosamines. Both are genotoxic and carcinogenic, and their metabolites lead to the formation of DNA adducts $^{29}$ (Table 1).

Maternal smoking during pregnancy produces negative effects on both the mother and the fetus through several pathways. These include the adverse effect of cigarette smoke on normal placental function, and the teratogenic effect of some cigarette metabolites. In addition, some metabolites of cigarette smoke act as vasoconstrictors reducing uterine blood flow by up to $38 \%,{ }^{31}$ seriously compromising the supply of oxygen and nutrients to the fetus, resulting in hypoxia-ischemia and malnutrition, which is the cause of fetal intrauterine growth retardation..$^{32}$ Also, carbon monoxide in cigarette smoke binds the hemoglobin creating carboxyhemoglobin, which inhibits release of oxygen to fetal tissues, resulting in tissue hypoxia. $^{33}$

In addition, nicotine, the predominant alkaloid in tobacco smoke, has extensive effects on fetal growth, maternal and fetal cardiovascular systems, the developing cerebral cortex, uter- 
ine vasoconstriction, developing respiratory epithelium, and umbilical and cerebral blood flow. Nicotine can easily cross the placenta and accumulates in the amniotic fluid where its level in the mid-trimester is $54 \%$ higher than those in maternal serum. The fetus swallows amniotic fluid, which, therefore, increases fetal intake of nicotine. This can reach levels in the fetal plasma up to $15 \%$ higher than those found in the mother. ${ }^{8}$ Nicotine causes a vasoconstrictive effect on the uterine and the umbilical artery ${ }^{8}$ It can also affect fetal brain development through activating nicotine receptors. ${ }^{34}$ Studies conducted on animal models showed that maternal nicotine exposure during pregnancy and lactation can induce transient structural changes in the testis and epididymis of male offspring. ${ }^{35}$

Nicotine has a short half-life, so it is not used as a marker for tobacco smoke exposure. Instead, cotinine and hydroxycotinine (which are the major metabolites of nicotine, the former being the major psychoactive substance found in cigarette smoke, ${ }^{36}$ had been used as specific biomarkers of cigarette smoking ${ }^{37}$ because they are easily detectable in human body fluids such as urine, saliva, ${ }^{36}$ and seminal plasma. ${ }^{38}$

Besides this, carbon monoxide, the second major product of tobacco smoke, can pass through the placenta to the fetus; carbon monoxide levels in fetal blood can reach levels approximately $15 \%$ higher than those in the mothers, ${ }^{39}$ causing a reduction in fetal oxygen supply resulting in fetal complications and health problems during the neonatal period. ${ }^{40-41}$

Many in vitro assay analyses were carried out to study the effect of tobacco smoke and its constituents on the pregnant and non-pregnant female reproductive system. ${ }^{42}$ So, generally, there are no recommended safe levels of exposure to cigarette smoke. ${ }^{43}$

\section{Adverse pregnancy complications due to smoking}

Many studies correlated the cause of adverse pregnancy outcomes to impaired fetal oxygen delivery throughout the pregnancy caused by maternal smoking.

Castles et al. conducted a meta-analysis to study the adverse effects of maternal smoking; they reported a statistically significant increase in the risks of placental abruption, placenta praevia, ectopic pregnancy and preterm pre-labor rupture of membranes. ${ }^{4}$

Maternal complications were detected in women aged 40 years and older, including, but not limited to, placental abruption, gestational diabetes, and placenta praevia. ${ }^{44-46}$ In addition, the relationship between maternal smoking and pregnancy outcomes is correlated to the age of the mother. ${ }^{47}$ However, another study showed that the relationship between maternal smoking and pregnancy outcomes is independent of maternal age. ${ }^{48}$

In order to determine whether women who continue to smoke in pregnancy and develop preeclampsia have a worse outcome than nonsmokers, and whether stopping smoking has an impact on outcomes, a cohort study conducted by Pipkin ${ }^{49}$ confirmed that pregnant smokers who developed preeclampsia had worse outcomes. However, women who stopped smoking had better outcomes. The relationships between maternal smoking with infertility and pregnancy complications are shown in Table 2.

\section{Infertility and delayed conception}

The conception rates in women non-smokers and former smokers appear to be similar, ${ }^{51}$ while pregnancy rates are lower in women smokers than non-smokers. ${ }^{52}$ Smoking also adversely affects the fecundity of women undergoing in vitro fertilization treatment. ${ }^{53}$ In addition, a systematic review of 12 studies of infertility showed that the odds ratio (OR) of infertility in women smokers versus non-smokers was 1.60 (95\% CI 1.34-1.91).$^{54}$ Moreover, higher infertility risk in women smokers was reported by de Mouzon and Belaisch-Allart. ${ }^{55}$

Lower levels of serum estradiol in women smokers than in non-smokers ${ }^{56}$ suggest that smoking appears to have antiestrogenic effects. ${ }^{57}$ Other studies found that the toxic products of cigarettes (especially nicotine) interfere with the maternal formation of corpus luteum, tubal transportation, and implantation. ${ }^{58}$

Another study aimed at determining whether passive and active smoking by women or smoking by men is associated with delayed conception, Hull et al. ${ }^{59}$ reported that, after adjustment for confounding factors, delayed conception was statistically significantly associated with both active and passive smoking by the woman.

\section{Placental abruption}

Placental abruption refers to a premature separation of the placenta from the uterine wall. It occurs in approximately $0.4-2 \%$ of all pregnancies and is one of the most common causes of maternal and perinatal death. ${ }^{60}$ Perinatal mortality rates due to placental abruption range from approximately 10 to $25 \%{ }^{60}$

Many studies have reported an association between maternal smoking during pregnancy and placental abruption, with odd ratios of $2.07,{ }^{61} 2.36,{ }^{62}$ and $2.5 .^{63}$ Placental abruption is correlated to smoking during pregnancy, and the risk increases according to the number of cigarettes smoked daily.64 Pregnant smokers risk placental abruption twice as much as nonsmokers. ${ }^{64-65}$ Rasmussen et al. ${ }^{66}$ suggested that smoking during pregnancy may cause degenerative and inflammatory alterations of the

Table 1. Constituents in whole tobacco. ${ }^{30}$

\begin{tabular}{|c|c|c|c|}
\hline Constituents & Examples & Constituents & Examples \\
\hline Alkaloids & $\begin{array}{l}\text { Nicotine } \\
\text { Nomiocotine } \\
\text { Anabasin } \\
\text { Anatabine }\end{array}$ & Nitrosamines & $\begin{array}{l}\text { NNN } \\
\text { NNK } \\
\text { NAT } \\
\text { NAB }\end{array}$ \\
\hline Metals & $\begin{array}{c}\text { Arsenic } \\
\text { Nickel } \\
\text { Lead } \\
\text { Cadmium } \\
\text { Chromium } \\
\text { Selenium } \\
\text { Mercury }\end{array}$ & Others & $\begin{array}{c}\text { Benzo }[a] \text { pyrene } \\
\text { Triacetine } \\
\text { Nitrate } \\
\text { Ammonia } \\
\text { Glycerol } \\
\text { Propylene }\end{array}$ \\
\hline
\end{tabular}

NNN, N-nitrosonornicotine; NNK, 4-(methylnitrosamino)-1-(3-pyridyl)-1-butanone; NAT, N-nitrosoanatabine; NAB, nitrosoanabasine.

Table 2. Smoking-related risks and pregnancy complications. ${ }^{50}$

\begin{tabular}{lc} 
Complications & Relative risk \\
Infertility & $1.2-3.6$ \\
Ectopic pregnancy & $1.5-2.5$ \\
\hline Spontaneous abortion & $1.0-1.8$ \\
Placental abruption & $1.4-2.4$ \\
\hline Placenta praevia & $1.5-3.0$ \\
Preeclampsia & $0.5-0.7$ \\
\hline
\end{tabular}

Relative risk: the ratio of the risk of disease or death among smokers to the risk of disease or death among non-smokers. 
placenta which will lead to placental abruption. Another study by Faruque et al. ${ }^{67}$ found a decrease in levels of ascorbic acid in pregnant smokers. In contrast, Sanchez et al. ${ }^{68}$ reported that smoking did not appear to be a risk factor in smoking Peruvian women.

\section{Placenta praevia}

Placenta praevia is defined as a placenta that partly or completely covers the internal cervical opening and is associated with maternal smoking during pregnancy. ${ }^{69-70}$ A positive correlation (OR 1.58\%) was reported between maternal smoking during pregnancy and placental praevia. ${ }^{4}$ In addition, a dose-related response was found between smoking and placenta praevia by which the chance of developing placenta praevia by pregnant women smokers increases in relationship to the increase in the number of cigarettes smoked. ${ }^{71-72}$

Placenta praevia in pregnant women smokers may occur as a result of internal cervical obstruction due to placental enlargement. Increasing levels of carbon monoxide and decreasing levels of oxygen in these women result in hypoxemia. This is thought to cause placental enlargement, which increases the risk of the placenta reaching the cervical opening.

\section{Spontaneous abortion}

Studies have shown that smoking increases the risk of spontaneous abortion. ${ }^{73-74}$ Estimates show that there is a $25 \%$ increased risk of spontaneous abortion in pregnant smokers compared with non-smokers, and this increase was also dose dependent. ${ }^{75}$ Consequently, the number of abortions increases with the number of cigarettes smoked. ${ }^{76}$

There was a strong correlation between both maternal and paternal smoking and the rate of spontaneous abortions. ${ }^{77-78}$ Tobacco smoke and cocaine use was found to be associated with a significant risk of spontaneous abortion. ${ }^{79}$

Nielsen et al. ${ }^{80}$ found supportive evidence that pre-pregnancy smoking is associated with spontaneous abortion and the risk of spontaneous abortion increases with the number of cigarettes smoked each day. ${ }^{80}$

In addition, some little support for an association between in utero exposure to tobacco smoke and risk of experiencing still birth in later life was provided recently by Cupul-Uicab et al. ${ }^{81}$

Generally, in women smokers, spontaneous abortion with normal fetal karyotype is higher than spontaneous abortion with abnormal fetal karyotype. ${ }^{82}$ The toxic effects of smoke constituents, such as nicotine, carbon monoxide, and other constituents of tobacco smoke, may increase the risk of spontaneous abortion with normal fetal karyotype.

In contrast, some studies failed to find a significant correlation between maternal smoking and spontaneous abortion. ${ }^{83-84}$ These results could be partially explained by the difference in the methodology used in the study, the reduced sample size, and the fact that few women were in the category of high tobacco consumption.

\section{Ectopic pregnancy}

Ectopic pregnancy is the term used to describe a pregnancy, which occurs outside the uterine cavity. ${ }^{85}$ It usually occurs in the fallopian tube. Ectopic pregnancy is one of the major causes of maternal death in the first trimester of pregnancy ${ }^{86}$ and may also affect future maternal fertility. The risk of ectopic pregnancy increases with smoking, ${ }^{87}$ and a dose response relationship was found between maternal cigarette smoking during conception and ectopic pregnancy. ${ }^{88}$ As the daily number of cigarettes smoked by pregnant woman increased, the chances of those women experiencing an ectopic pregnancy were 5 times higher than for pregnant non-smokers. ${ }^{89}$

Cigarette smoking is correlated with an increased risk of pelvic inflammatory disease (PID), which is one of the most important risk factors for ectopic pregnancy. This partly explains why smoking increases the risk of ectopic pregnancy. ${ }^{64}$

\section{Adverse pregnancy outcomes due to smoking}

Cigarette smoking itself is one of the leading contributors to death, ${ }^{90}$ whereas maternal smoking during pregnancy has been implicated as a potential risk factor correlated with multiple negative child outcomes, such as low birth weight, conduct disorder, attention deficit hyperactivity disorder, child smoking and cognitive dysfunction. ${ }^{91}$

A recent study by Agrawal et al..$^{92}$ reported that maternal smoking during pregnancy may influence certain outcomes in offspring via mechanisms that are independent of genetic risk attributable to comorbid conditions.

Pregnant women over the age of 40 and older experienced fetal complications including perinatal mortality, preterm birth, and low

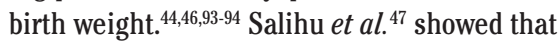
in utero fetal death was highest among older

Table 3. Smoking-related risks and adverse pregnancy outcomes. ${ }^{50}$

\begin{tabular}{lc} 
Complications & Relative risk \\
Small for gestational age & $1.5-2.9$ \\
Preterm birth & $1.2-1.6$ \\
\hline Stillbirth & $1.3-1.8$ \\
Neonatal mortility & $1.2-1.4$ \\
\hline Congenital malformation (oral cleft) & $1.2-1.6$ \\
\hline
\end{tabular}

Relative risk, the ratio of the risk of disease or death among smokers to the risk of disease or death among non-smokers.

smoking mothers ( $\geq 40$ years) and declined with decreasing age (trend $\mathrm{P}<0.0001$ ). This could indicate that the relationship between maternal smoking and pregnancy outcomes is correlated to the age of the mother.

The toxic effects of smoking during pregnancy vary from perinatal complications, such as low birth weight, to changes in adult behavior. $^{95-99}$ Table 3 shows the reported results of smoking and risks of adverse pregnancy outcomes from studies.

\section{Fetal growth retardation}

Fetal growth retardation is associated to maternal smoking. ${ }^{50}$ Active smoking during pregnancy is a well-established cause of fetal growth retardation. ${ }^{100-102}$ Infants born to mothers who smoke are three times more likely to have low birth-weight than infants born to mothers who are non-smokers ${ }^{103}$ and these infants may die during infancy. ${ }^{104}$ In addition, the number of cigarettes smoked by pregnant women each day showed a significant negative correlation with newborn weight, body mass index, length and head circumference. ${ }^{105}$ Maternal smoking during pregnancy causes a delay in fetal growth, which is greater in male offspring. Also, intrauterine growth concerning weight, length and head circumference in the offspring of mothers who smoked decreased with parity, whereas they increased in smoking mothers during pregnancy.48 Several studies reported a greater weight reduction in male than in female offspring of heavy-smoking ( $>10$ cigarettes per day) pregnant women. ${ }^{105-108}$ In pregnant smokers, higher arterial resistance indices and lower birth weights were observed. These findings were associated with increasing levels of tobacco smoking exposure. The values were significantly different to those found in non-smoking pregnant women. ${ }^{109}$

Pringle et al. ${ }^{110}$ reported that smoking during pregnancy resulted in altered placental appearance on ultra-sonography, increased umbilical artery blood flow resistance, and a reduction in longitudinal and intra-abdominal organ growth.

Other factors may interact with the effect of smoking on fetal growth such as; maternal age, ${ }^{111}$ genetic factors, ${ }^{112}$ and pregnancy

[Teratology Studies 2012; 2:e1]

[page 3] 
weight. $^{62}$ In another study conducted by Cnattingius et al., ${ }^{113}$ the effect of maternal age, smoking, and parity as a dichotomous variable on newborn birth weight were studied and they found that the odds ratio for the delivery of low-birth-weight neonates increases with age, smoking and parity, and these parameters are significantly interrelated. ${ }^{114}$

The negative effect of smoking during pregnancy on fetal growth remains unclear.

Maternal hormones and placenta play an important role in fetal growth. ${ }^{115-117}$ In addition, fetal hormone concentrations were affected by maternal smoking during pregnancy ${ }^{118-120}$ which adversely affect fetal growth and may increase the blood pressure of the neonates and infants of these mothers ${ }^{121-122}$ Also, the detection of low concentrations of leptin in the cord blood of both preterm and term newborn infants of smoking mothers could be associated with fetal growth retardation. ${ }^{114,123}$

\section{Preterm birth}

Preterm birth refers to the birth that occurs before 37 weeks of conception (4 weeks before estimated date of birth). Two-thirds of all preterm births occur spontaneously, while onethird are electively delivered due to concerns about fetal or maternal health. Smoking is associated with both outcomes and is considered to be one of the major causes of neonatal mortality and morbidity. The risk of preterm birth increased as the number of cigarettes increased. ${ }^{124-125}$ Smoking is responsible for $15 \%$ of all cases of premature labor. ${ }^{126}$ In addition, a relationship between heavy smoking pregnant French women with low obstetric risk and preterm birth was reported. ${ }^{127}$

Moreover, presence of previous adverse pregnancy outcomes is considered to be one of the strongest risk factors for preterm delivery. ${ }^{128-130}$ Other researchers showed that other risk factors, such as low socioeconomic status, ${ }^{131}$ was associated with preterm delivery among women with a low obstetric risk but not with women with previous adverse pregnancy outcomes. Reports showed that the most frequent reason for preterm birth is preterm premature rupture of membranes (PRM), representing almost $30 \%$ of all preterm deliveries, and women who smoked during pregnancy had a 2.1 times greater risk of preterm birth compared to non-smokers. ${ }^{132-133}$

Along with preterm rupture of membranes, ${ }^{134}$ smoking increases the risk of preterm birth by increasing the secretion of prostaglandins in fetal membranes. ${ }^{135}$ On the other hand, stopping smoking was found to lengthen the gestational period. ${ }^{136}$

In a 2009 prospective cohort study conducted by McCowan et al., ${ }^{137}$ an association was reported between both spontaneous preterm birth and infants small for gestational age with women smokers who stop smoking early in pregnancy. In contrast, some studies failed to report a correlation between smoking and preterm birth. ${ }^{138-140}$

\section{Perinatal death}

Perinatal death represents both stillbirth and early neonatal death. ${ }^{141}$ Smoking was found to be the cause of unexplained stillbirth $^{142}$ and one-third of neonatal deaths in the UK. ${ }^{143}$ Smoking during pregnancy was associated with a $10 \%$ increase in prenatal mortality and an increase in the incidence of premature labor and placental abruption. ${ }^{144}$ Other studies also showed that maternal smoking is associated with premature labor and perinatal mortality reaching approximately $150 \%$ higher rates in smoking mothers than in non-smoking mothers. ${ }^{145}$

The adverse effect of maternal smoking during pregnancy increased the prenatal and infant mortality rates. ${ }^{146}$ Maternal smoking during pregnancy remains an important determinant of a late fatal and infant mortality rate ${ }^{61}$

The results of many studies support the hypothesis that there is a fundamental relationship between smoking and risk of perinatal death ${ }^{147-149}$ which could be correlated to high rates of placental abruption and placenta praevia. ${ }^{148}$ In addition, about $40 \%$ of the babies of smoking mothers die within the first four weeks of life. ${ }^{106}$ Some studies also correlate passive smoking with infant Sudden Death Syndrome. ${ }^{150-151}$

\section{Congenital dysfunction, impaired learning and behavioral problems}

Many epidemiological studies showed that maternal cigarette smoking during pregnancy can lead to complications in the fetal nervous system, resulting in behavioral disturbances in infancy, childhood, and even in early adulthood. ${ }^{152-153}$ Impaired learning in children prenatally exposed to cigarette smoke was reported by several studies. . $^{154-156}$

In 2001, Cornelius et al. ${ }^{157}$ correlated maternal smoking during pregnancy with deficits in multiple aspects of learning and memory. In addition, Lambe et al. ${ }^{155}$ reported another correlation between maternal smoking during pregnancy via familial factors and poor school performance.

Law et al. ${ }^{158}$ conducted a bioassay test of smoking exposure to newborn neurobehavior and reported a dose-response relationship between them. These findings suggest neurotoxic effects of prenatal tobacco exposure on newborn neurobehavior.

This relationship could be linked to the nicotine in cigarette smoke, which was found to be a neuroteratogen factor that interferes with the development of the fetal nervous system. ${ }^{159}$ Nicotine binds with nicotinic acetylcholine receptors in the fetal brain affecting cell prolif- eration and differentiation. Upregulation of nicotinic cholinergic receptor due to nicotine exposure leads to abnormalities in the development of synaptic activity ending with neuronal damage. ${ }^{160}$ Low doses of nicotine restrict fetal brain development even if they do not affect the fetal birth weight. ${ }^{161}$ Also, smoking during pregnancy correlated with mild neuro-developmental handicaps. ${ }^{162}$ Moreover, a 2011 study conducted by Suarez et al. ${ }^{163}$ suggested that maternal exposure to passive smoke is associated with neural tube defects (NTDs). ${ }^{163}$

Several studies examining the effect of smoking on children's behavior demonstrated an association between maternal smoking and behavioral problems among children. ${ }^{164}$ Also, the effect of postnatal tobacco exposure on behavioral development was suggested. ${ }^{165} \mathrm{~A}$ prospective cohort study conducted by Rückinger et al. ${ }^{166}$ to assess the relative risk of behavioral problems in children who had been subjected to in utero and postnatal exposure to tobacco smoke, showed a strong association between in utero exposure to smoking and several parameters of abnormal behavioral. ${ }^{166}$

\section{Effects of passive smoking on birth weight}

Passive smoking or environmental tobacco smoke (ETS), or second-hand smoke or involuntary smoking has been shown to be one of the major causes of health problems. ${ }^{167,168}$

Side-stream smoke represents about $85 \%$ of the smoke present in any one place. It contains many toxic gaseous substances in higher concentrations than in the mainstream smoke. ${ }^{169}$ Passive smoking during pregnancy is associated with a more than 2 -fold higher risk of having a small-for-gestation baby. ${ }^{170}$

A reduction in birth weight was correlated to maternal exposure to passive smoking (to complete the analysis $)^{171-173}$ in a systematic review and meta-analysis conducted in 2008 to determine the effects of passive smoking exposure on birth outcomes. The authors reported that the exposure of non-smoking pregnant women to passive smoking reduces mean birth weight by $33 \%$ or more, and increases the risk of birth weight below $2500 \mathrm{~g}$ by $22 \%$; however, it has no clear effect on gestation or the risk of being small-for-gestation age. ${ }^{174}$

\section{Mutation in newborns due to active and passive smoking}

Maternal smoking and secondary exposure to environmental tobacco smoke (ETS) not only have deleterious effects on the developing 
fetus, but they may have life-long consequences due to genotoxic damage. Cancer in the adult and in utero teratogenicity are associated with exposure to tobacco smoke metabolites. $^{2}$

Both maternal active smoking and passive smoking to ETS cause similar mutational induction in those mothers. The molecular base of mutational induction is chromosome missagregation, resulting in an effective loss of one parental chromosome 4 and duplication of the other. ${ }^{175}$

Grant ${ }^{176}$ found the same level of mutation of the HPRT gene in both newborns subjected to passive smoking ETS and those subjected to active maternal smoking. Recently, the same author found that similar levels and types of genotoxic damage in the developing fetus were induced by smoking in both active and passive maternal smoking. ${ }^{177}$ Also, a combined effect between maternal genetic polymorphisms and smoking during pregnancy was reported by Sasaki et al. ${ }^{178}$

Recently, Grazuleviciene et al. suggested that even low levels of smoking ought to be considered a potential risk factor for adverse birth outcomes, and that genetic polymorphism may contribute to individual variation in tobacco smoke response. ${ }^{179}$

\section{Maternal smoking in pregnancy and childhood respiratory system complications}

Maternal smoking during pregnancy is a well known cause of fetal growth retardation. Moreover, many studies suggested a positive correlation between maternal smoking during pregnancy and fetal respiratory system, which may result in impaired lung function in newborns. ${ }^{180-185}$ Smoking may also damage the fetal respiratory system, either to the bronchial tree or to the blood vessels of the fetal lung, the same as has been shown in the umbilical vessels. ${ }^{186}$ Cigarette smoking was found to be an immunosuppressive agent both in vivo and in vitro, which predisposes the infant to respiratory infections. ${ }^{187}$ Epidemiological studies indicate that maternal smoking is a risk factor for asthma in childhood. ${ }^{188-190}$

Steffensen et al. ${ }^{191}$ reported a correlation between low birth weight and subsequent childhood asthma. Similar findings were reported by Jaakkola and Gissler ${ }^{99}$ who reported that maternal smoking increased the risk of asthma (adjusted $\mathrm{OR}=1.35 ; 95 \%$ confidence interval=1.13, 1.62 for high exposure). In addition, low birth weight and preterm delivery were reported to increase the risk of asthma at the age of seven.

Other research groups have also provided evidence that correlated maternal smoking during pregnancy with childhood asthma. ${ }^{192-198}$

Many studies have illustrated the relationship between parental smoking and otitis media in children. Among these, a study by Haberg et $a l .{ }^{199}$ aimed to explore associations between acute otitis media (AOM) in early childhood and prenatal and postnatal tobacco smoke exposure. They concluded that relatively low exposure levels of parental and/or maternal smoking in pregnancy was associated with an increased risk of acute otitis media in early childhood.

Putting together all the data examined in this review, we can recognize that tobacco smoke still has many other negative effects. Among these it was found that prenatal smoke exposure causes alteration in gene expression during the early period of hippocampal growth (brain tissue) in mice and may result in abnormal hippocampal morphology, connectivity and function. ${ }^{200}$

\section{Conclusions}

Smoking in women of reproductive age can be associated to both fetal and maternal complications in pregnancy. Smoking is well known to have adverse effects on pregnancy. Fetal exposure to passive smoking from the mother may seriously affect childhood health with possible consequences in adult life.

Physicians should clarify these hazardous effects to pregnant women and advise them strongly to stop smoking as soon as possible. If they continue smoking they should be considered a high-risk pregnancy. Governments should cooperate with the World Health Organization to introduce well organized health education programs, encouraging women to stop smoking and discouraging young girls from starting.

\section{References}

1. Ockene J, Emmons K, Mermelstein R, et al. Relapse and maintenance issues for smoking cessation. Health Psychol 2000;19:17-1.

2. IARC, International Agency for Research on Cancer; Working Group on the Evaluation of Carcinogenic Risks to Humans. Tobacco smoke and involuntary smoking. IARC Monogr Eval Carcinogen Risks Hum 2004;83:1-1438.

3. Windsor RA. Smoking, cessation and pregnancy. In: JM Samet, SY Yoon (eds.) Women and the tobacco epidemic: challenges for the 21st century. Geneva: The World Health Organization; 2001. pp. 147-4.
4. Castles A, Adams EK, Melvin CL, et al. Effects of smoking during pregnancy. Five meta-analyses. Am J Prevent Med 1999;16:208-5.

5. Lindley AA, Becker S, Gray RH, Herman AA. Effect of continuing or stopping smoking during pregnancy on infant birth weight, crown-heel length, head circumference, ponderal index and brain:body weight ratio. Am J Epidemiol 2000;152:219-25.

6. Mitchell EA, Thompson JM, Robinson E, et al. Smoking, nicotine and tar, and risk of small for gestational age babies. Acta Paediatr 2002;91:323-8.

7. Ananth CV, Smulian JC, Bintzileos AM. Incidence of placental abruption in relation to cigarette smoking and hypertensive disorders during pregnancy: a meta analysis of observational studies. Obstet Gynecol 1999;93:622-7.

8. Saraiya M, Berg CJ, Strauss LT, et al. Cigarette smoking as a risk factor for ectopic pregnancy. Am J Obstet Gynecol 1998;178:493-8.

9. Lambers DS, Clarke KE. The maternal and fetal physiologic effects of nicotine. Semin Perinatol 1996;20:115-6.

10. Rogers JM. Tobacco and pregnancy. Reprod Toxicol 2009;28:152-60.

11. Meyer S, Raisig A, Gortner L, et al. In utero tobacco exposure: the effects of heavy and very heavy smoking on the rate of SGA infants in the Federal State of Saarland, Germany. Eur J Obstet Gynecol Rep Biol 2009;146:37-40.

12. Vogt Isaksen C. Maternal smoking, intrauterine growth restriction, and placental apoptosis. Pediatr Dev Pathol 2004;7:433-42.

13. Orhon FS, Ulukol B, Kahya D, et al. The influence of maternal smoking on maternal and newborn oxidant and antioxidant status. Eur J Pediatr 2009;168:975-81.

14. Bolisetty S, Naidoo D, Lui K, et al. Postnatal changes in maternal and neonatal plasma antioxidants vitamins and the influence of smoking. Arch Dis Child Neonatal 2002;86:36-40.

15. Fayol L, Gulian JM, Dalmasso C, et al. Antioxidant status of neonates exposed in utero to tobacco smoke. Biol Neonate 2005;87:121-6.

16. Ermis B, Ors R, Yildirim A, et al. Influence of smoking on maternal and neonatal serum malondialdehyde, superoxide dismutase, and glutathione peroxidase levels. Ann Clin Lab Sci 2004;34: 405-9.

17. Arguelles S, Machado MJ, Ayala A, et al. Correlation between circulating biomarkers of oxidative stress of maternal and umbilical cord blood at birth. Free Radic Res 2006;40:565-70. 
18. Aycicec A, Ipek A. Maternal active or passive smoking causes oxidative stress in cord blood. Eur J Pediatr 2008;167:81-5.

19. Aycicec A, Erel 0, Kocyigit A. Increased oxidative stress in infants exposed to passive smoking. Eur J Pediatr 2005;164: 775-8.

20. Schwarz KB, Cox JM, Sharma S, et al. Prooxidant effects of maternal smoking and formula in newborn infants. J Pediatr Gastroenterol Nutr 1997;24:6874.

21. Westbrook DG, Anderson PG, Pinkerton KE, Ballinger SW. Perinatal tobacco smoke exposure increases vascular oxidative stress and mitochondrial damage in non-human primates. Cardiovasc Toxicol 2010;10:216-26.

22. Chelchowska M, Ambroszkiewicz J, Gajewska J, et al. The effect of tobacco smoking during pregnancy on plasma oxidant and antioxidant status in mother and newborn. Eur J Obstet Gynecol Reprod Biol 2011;155:132-6.

23. Dechanet C, Anahory T, Mathieu, et al. Effects of cigarette smoking on reproduction. Hum Reprod Update 2011;171:76-5.

24. Smith CJ, Fischer TH. Particulate and vapour phase constituents of cigarette mainstream smoke and the risk of myocardial infarction. Atheroscl 2001; 1582:257-67.

25. Fowles J, Bates M. The chemical constituents in cigarettes and cigarette smoke: priorities for harm reduction. Porirua, New Zealand: Epidemiology and Toxicology Group, Institute of Environmental Science and Research Ltd.; 2000.

26. Halliwell B, Poulsen HE. Cigarette smoke and oxidative stress. New York: Springer; 2006.

27. Brunnemann KO, Qi J, Hoffmann D. Chemical profile of two types of oral snuff tobacco. Food Chem Toxicol 2002;4011:1699-703.

28. Hoffmann D, Wynder EL. Chemical constituents and bioactivity of tobacco smoke. IARC Scientific Publications 1986;74:145-5.

29. Sasaki S, Sata F, Katoh S, et al. Adverse birth outcomes associated with maternal smoking and polymorphisms in the $\mathrm{N}$ nitrosamine-metabolizing enzyme genes NQ01 and CYP2E1. Am J Epidemiol 2008;167:719-26.

30. Hammond D, O'Connor RJ. Constituents in tobacco and smoke emissions from Canadian cigarettes. Tob Control 2008; 17;i24-i31.

31. Suzuki K, Minei LJ, Johnson EE. Effect of nicotine upon uterine blood flow in the pregnant rhesus monkey. Am J Obstet Gynecol 1980;136:1009-13.

32. Ganapathy V, Prasad PD, Ganapathy ME,
Leibach FH. Drugs of abuse and placental transport. Adv Drug Deliv Rev 1999; 38:99-100.

33. Salafia C, Shiverick K. Cigarette smoking and pregnancy II: Vascular effects. Placenta 1999;20:273-9.

34. Hellstrom-Lindahl E, Nordberg A. Smoking during pregnancy: a way to transfer addiction to the next generation? Respiration 2002;69:289-93.

35. Lagunov A, Anzar M, Sadeu JC, et al. Effect of in utero and lactational nicotine exposure on the male reproductive tract in peripubertal and adult rats. Reprod Toxicol 2011;314:418-23.

36. Zenzes MT, Reed TE, Wang P, Klein J. Cotinine, a major metabolite of nicotine, is detectable in follicular fluids of passive smokers in vitro fertilization therapy. Fertil Steril 1996;66:614-9.

37. Hulka BS. Epidemiological studies using biological markers: issues for epidemiology. Cancer Epidemiol Biomarkers 1991; 1:13-9.

38. Pacifici R, Alteri I, Gandini L, et al. Nicotine, cotinine, and trans-3 hydroxycotinine levels in seminal plasma of smokers: effects on sperm parameters. Ther Drug Monit 1993;15:358-63.

39. Hill E, Hill J, Power G, Longo L. Carbon monoxide exchanges between the human fetus and mother: a mathematical model. Am J Physiol 1977;232:H311-3.

40. Benowitz N. Nicotine replacement therapy during pregnancy. JAMA 1991;266: 3174-7.

41. Perry CL, Silvis GL. Smoking Prevention: Behavioural prescriptions for the pediatrician. Pediatrics 1987;79:790-9.

42. Talbot P. In vitro assessment of reproductive toxicity of tobacco smoke and its constituents. Birth Defects Res C Embryo Today 2008;84:61-72.

43. Zhu BQ, Heeschen C, Sievers RE, et al. Second hand smoke stimulates tumor angiogenesis and growth. Cancer Cell 2003;4:191-6.

44. Berkowitz GS, Skovron ML, Lapinski RH, Berkowitz RL. Delayed childbearing and the outcome of pregnancy. N Engl J Med 1990;322:659-744.

45. Fretts RC, Schmittdiel J, Mclean FH, et al. Increased maternal age and the risk of fetal death. N Engl J Med 1995;333: 953-7.

46. Bianco A, Stone J, Lynch L, et al. Pregnancy outcome at age 40 and older. Obstet Gynecol 1996;87:917-22.

47. Salihu HM, Shumpert MN, Aliyu MH, et al. Stillbirths and infant deaths associated with maternal smoking among mothers aged 540 years: a population study. Am J Perinatol 2004;213:121-6.

48. Varvarigou AA, Asimakopoulou A, Beratis
NG. Impact of maternal smoking on birth size: effect of parity and sex dimorphism. Neonatol 2009;95:61-7.

49. Pipkin FB. Smoking in moderate/severe preeclampsia worsens pregnancy outcome, but smoking cessation limits the damage. Hypertension 2008;51;1042-6.

50. Cnattingius S. The epidiomology of smoking during pregnancy: smoking prevalence, maternal characteristics and pregnancy outcomes. Nicotine Tob Res 2004;6:S125-40.

51. Curtis K M, Savitz DA, Arbuckle TE. Effects of cigarette smoking, caffeine consumption, and alcohol intake on fecundability. Am J Epidemiol 1997;146: $32-41$.

52. Florack EI, Zielhuis GA, Rolland R. Cigarette smoking, alcohol consumption, and caffeine intake and fecundability. Prevent Med 1994;232:175-80.

53. Hughes EG, Brennan BG. Does cigarette smoking impair natural or assisted fecundity? Fertil Steril 1996;66:679-89.

54. Augood C, Duckitt K, Templeton AA. Smoking and female infertility: a systematic review and meta-analysis. Hum Reprod 1998;13:1532-9.

55. de Mouzon J, Belaisch-Allart J. Consequences on women's fecundity and on assisted reproductive technology. J Gynecol Obstet Biol Reprod 2005;34:112-8.

56. Gustafson 0, Nylund L, Carlstrom K. Does hyperandrogenism explain lower in vitro fertilization (IVF) success rates in smokers? Acta Obstet Gynecol Scand 1996;75:149-56.

57. Baron JA, La Vecchia C, Levi F. The antiestrogenic effect of cigarette smoking in women. Am J Obstet Gynecol 1990; 162:502-4.

58. Gindoff PR, Tidey GF. Effects of smoking on female fecundity and early pregnancy outcome. Semin Reprod Endocrinol 1989;7:305-13.

59. Hull MGR, North K, Taylor H, et al. Delayed conception and active and passive Smoking. Fertil Steril 2000;74:72533.

60. Kyrklund-Blomberg NB, Gennser G, Cnattingius S. Placental abruption and perinatal death. Paediatr Perinat Epidemiol 2001;5:290-7.

61. Tuthill DP, Stewart JH, Coles EC, et al. Maternal cigarette smoking and pregnancy outcome. Paediatr Perinat Epidemiol 1999;13:245-53.

62. Spinillo A, Capuzzo E, Collona C, et al. Factors associated with abruption placenta in preterm deliveries. Acta Obstet Gynacol 1994;74:307-12.

63. Eriksen G, Wolhert M, Ersbak V, et al. Placental abruption: a case control investigation. Br J Obstet Gynecol 1991;98: 
448-52.

64. US Department of Health and Human Services. Health consequences of tobacco use among women. In: Women and smoking: A report of the surgeon general. Department of Health and Human Services, Centers for Disease Control and Prevention, National Center for Chronic Disease Prevention and Health Promotion, Office of Smoking and Health, Rockville, MD, USA; 2001. pp. 177-450.

65. Ananth CV, Smulian JC, Demissie K, et al. Placental abruption among singleton and twin births in the United States: Risk factor profiles. Am J Epidemiol 2001;153:771-8.

66. Rasmussen S, Irgens LM, Dalaker K. A history of placental dysfunction and risk of placental abruption. Paediatr Perinat Epidemiol 1999;13:9-11.

67. Faruque M0, Khan MR, Rahman MM, Ahmed F. Relationship between smoking and antioxidant nutrient status. $\mathrm{Br} \mathrm{J}$ Nutr 1995;73:625-32.

68. Sanchez SE, Pacora PN, Farfan JH. Risk factors of abruptio placentae among Peruvian women. Am J Obstet Gynecol 2006;194:225-30.

69. Chelmow D, Andrew DE, Baker ER. Maternal cigarette smoking and placenta praevia. Obstet Gynecol 1996;87:703-12.

70. Zhang J, Friel DB. Relationship of maternal smoking during pregnancy to placenta praevia. Am J Prevent Med 1992;8:27885.

71. Meyer M, Tonascia J. Perinatal events associated with maternal smoking during pregnancy. Am J Epidemiol 1976; 1103:464-76.

72. Ananth CV, Demissie K, Smulian JC, Vintzileos AM. Placenta praevia in singleton and twin births in the United States, 1989 through 1998: A comparison of risk factor profiles and associated conditions. Am J Obstet Gynecol 2003;188: $275-81$.

73. Kline J, Stein Z, Susser M, Warburton D. Smoking: a risk factor for spontaneous abortion. N Engl J Med 1997;297:793-6.

74. Himmelberger D, Brown B, Cohen E. Cigarette smoking during pregnancy and the occurrence of spontaneous abortion and congenital abnormality. Am J Epidemiol 1978;108:470-9.

75. United States Department of Health and Human Services. The Health Consequences of Smoking: Nicotine Addiction. A report of the Surgeon General. Centres for Disease Control and Prevention: National Centre for Health Statistics, Washington DC, USA; 1988.

76. Armstrong BG, McDonald AD, Sloan M. Cigarette, alcohol and coffee consump- tion and spontaneous abortion. Am J Pub Heal 1992;82:85-7.

77. Chatenoud L, Parazzini F, di Cintio E, et al. Paternal and maternal smoking habits before conception and during the first trimester: relation to spontaneous abortion. Ann Epidemiol 1998;8:520-6.

78. Windham GC, Swan SH, Fenster L. Parental cigarette smoking and the risk of spontaneous abortion. Am J Epidemiol 1992;135:1394-403.

79. Ness RB, Grisso JA, Hirschenger N, et al. Cocaine and tobacco use and the risk of spontaneous abortion. N Engl J Med 1999;340:333-9.

80. Nielsen A, Hannibal CG, Lindekilde BE, et al. Maternal smoking predicts the risk of spontaneous abortion. Acta Obstet Gynecol 2006;85:1057-65.

81. Cupul-Uicab LA, Baird DD, Skjaerven R, et al. In utero exposure to maternal smoking and women's risk of fetal loss in the Norwegian Mother and Child Cohort (MoBa). Hum Reprod 2011;26:458-65.

82. Kline J, Levin B, Kinney A, et al. Cigarette smoking and spontaneous abortion of known karyotype. Precise data but uncertain inferences. Am J Epidemiol 1995;141:417-27.

83. Rasch V. Cigarette, alcohol and caffeine consumption: risk factors for spontaneous abortion. Acta Obstet Gynecol Scand 2003;82:182-8.

84. Wisborg K, Kesmodel U, Henriksen TB, et al. A prospective study of maternal smoking and spontaneous abortion. Acta Obstet Gynecol Scand 2003;82:936-41.

85. Creatsas G. Modern obstetrics and gynecology. Gynecology. Athens: Paschalidis PH; 1998. pp. 313.

86. Confidential Enquiries into Maternal and Child Health (CEMACH). Why mothers die: report of the confidential enquiries into maternal deaths in the United Kingdom. 1997-1999. London: RCOG Press; 2001.

87. Poswillo D, Alberman E. Effects of smoking on the fetus, neonate and child. Oxford University Press, UK, 1992.

88. Coste J, Job-Spira N, Fernandez H. Increased risk of ectopic pregnancy with maternal cigarette smoking. Am J Publ Heal 1991;81:199-201.

89. Handler A, Davis F, Ferre C, Yeko T. The relationship of smoking and ectopic pregnancy. Am J Public Health 1989;79: 1239-42.

90. Centers for Disease Control (CDC). Annual smoking-attributable mortality, years of potential life lost, and economic costs-United States. MMWR Morb Mortal Wkly Rep 2001;51:300-3.

91. Knopik VS. Maternal smoking during pregnancy and child outcomes: real or spurious effect? Dev Neuropsychol 2009; 34:1-6.

92. Agrawal A, Scherrer JF, Grant JD, et al The effects of maternal smoking during pregnancy on offspring outcomes. Prevent Med 2010;50:13-8.

93. Prasad M, Ghosh S, Al-Taher H. Obstetric outcome in women over the age of 40 years. J Obstet Gynaecol 2000;20:24-6.

94. Cnattingius S, Forman MR, Berendes HW, Isotalo L. Delayed childbearing and risk of adverse perinatal outcome. JAMA 1992;268:886-90.

95. Walsh RA, Lowe JB, Hopkins PJ. Quitting smoking in pregnancy. Med J 2001;175: 320-3.

96. Jakab Z. Smoking and pregnancy. Acta Obstet Gynecol Scand 2010;89:416-7.

97. Braun JM, Daniels JL, Kalkbrenner A, et al. The effect of maternal smoking during pregnancy on intellectual disabilities among 8-year-old children. Paediatr Perinat Epidemiol 2009;23:482-91.

98. Kyu HH, Georgiades K, Boyle $\mathrm{MH}$. Maternal smoking, biofuel smoke exposure and child height-for-age in seven developing countries. Int $\mathrm{J}$ Epidemiol 2009;38:1342-50

99. Jaakkola JJ, Gissler M. Maternal smoking in pregnancy, fetal development,

and childhood asthma. Am J Public Health 2004;94:136-40.

100. Donald JM, Hooper K, Hopenhayn-Rich C. Reproductive and developmental toxicity of toluene: A review. Environ Health Perspect 1991;94:237-44.

101. Seidenberg JM, Anderson DG, Becker RA. Validation of an in vivo developmental toxicity screen in the mouse. Teratog Carcinog Mutagen 1986;6:361-74

102. Longo LD. The biological effects of carbon monoxide on the pregnant woman, fetus, and newborn infant. Am J Obstet Gynecol 1977;129:69-73.

103. Royal College of Physicians. Smoking and the young. London: Royal College of Physicians; 1992.

104. Kramer MS. Determinants of low birth weight: methodological assessment and meta-analysis. Bull World Health Organ 1987;65: 663-7.

105. Kanellopoulos TA, Varvarigou AA, Karatza AA, Beratis NG. Course of growth during the first 6 years in children exposed in utero to tobacco smoke. Eur J Pediatr 2007;166:685-92.

106. Ahlsten G, Cnattingious S, Lindmark G. Cessation of smoking during pregnancy improves fetal growth and reduces infant morbidity in the neonatal period: a population based prospective study. Acta Paediatr 1993;82:177-81.

107. Zaren B, Lindmark G, Bakketeig L. Maternal smoking affects fetal growth 
more in the male fetus. Pediatr Perinat Epidemiol 2000;14:118-26.

108. Wertelecki W, Hoff C, Zansky S. Maternal smoking: greater effect on males, fetal tobacco syndrome? Teratology 1987;35:3 17-20.

109. Machado HB, Filho PM, Petersen G0, Chatkin JM. Quantitative effects of tobacco smoking exposure on the maternal-fetal circulation. BMC Pregnancy Childbirth 2011;11:24.

110. Pringle PJ, Geary MP, Rodeck $\mathrm{CH}$, et al. The influence of cigarette smoking on antenatal growth, birth size and the insulin-like growth factor axis. J Clin Endocrinol Metabol 2005;90:2568-72

111. Fox SH, Koepsell TD, Daling JR. Birth weight and smoking during pregnancyeffect modification by maternal age. Am J Epidemiol 1994;139:1008-15.

112. Wang X, Zuckerman B, Pearson C, et al. Maternal cigarette smoking, metabolic gene polymorphism, and infant birth weight. JAMA 2002;287:195-202.

113. Cnattingius S, Forman MR, Berendes HW, et al. Effect of age, parity, and smoking on pregnancy outcome: a population based study. Am J Obstet Gynecol 1993; 168:16-21.

114. Mantzoros CS, Varvarigou A, Kaklamani VG, et al. Effect of birth weight and maternal smoking on cord blood leptin concentrations of full-term and preterm newborns. J Clin Endocrinol Metab 1997;82:2856-61.

115. Eriksson JG, Forsen T, Tuomilehto J, et al. Effects of size at birth and childhood growth on the insulin resistance syndrome in elderly individuals. Diabetologia 2002;45:342-58.

116. Carlsen SM, Jacobsen G, Romunstad P. Maternal testosterone levels during pregnancy are associated with offspring size at birth. Eur J Endocrinol 2006;155: 365-70.

117. Bauer MK, Harding JE, Bassett NS, et al. Fetal growth and placental function. Mol Cell Endocrinol 1998;140:115-20.

118. Beratis NG, Varvarigou A, Makri M, Vagenakis AG. Prolactine, growth hormone and insulin-like growth factor-I in newborn children of smoking mothers. Clin Endocrinol 1994;40:179-85.

119. Varvarigou AA, Beratis MG, et al. Increased levels and positive correlation between erythropoietin and hemoglobin concentrations in newborn children of mothers who are smokers. J Pediatr 1994;124:480-2.

120. Varvarigou A, Petsali M, Vassilakos P, Beratis NG. Increased cortisol concentrations in the cord blood of newborns whose mothers smoked during pregnancy. J Perinat Med 2006;34:466-70.
121. Beratis NG, Panagulias D, Varvarigou A. Increased blood pressure in neonates and infants whose mothers smoked during pregnancy. J Pediatr 1996;128:80612.

122. Beratis NG, Varvarigou A, Katsibris J, Gartaganis SP. Vascular retinal abnormalities in neonates of mothers who smoked during pregnancy. J Pediatr 2000;136:760-6.

123. Varvarigou A, Mantzoros CS, Beratis NG. Cord blood leptin concentrations in relation to intrauterine growth. Clin Endocrinol 1999;50:177-83.

124. Berkowitz GS, Papiernik E. Epidemiology of preterm birth. Epidemiol Rev 1993;15: 414-23.

125. Kyrklund-Blomberg NB, Cnattingius S. Preterm birth and maternal smoking: Risks related to gestational age and onset of delivery. Am J Obstet and Gynaecol 1998;179:1051-5.

126. Ventura SJ, Martin JA, Taffel SM, et al. Advance report of final natality statistics, 1993. Mon Vital Stat Rep 1995;44:1-8.

127. Nabet C, Ancel P, Burguet A, Kaminski M. Smoking during pregnancy and preterm birth according to obstetric history: French national perinatal surveys. Paediatr Perinat Epidemiol 2005;19:8896.

128. Foix-L'Hélias L, Blondel B. Changes in risk factors of preterm delivery in France between 1981 and 1995. Paediatr Perinat Epidemiol 2000;14:314-23.

129. Cnattingius S, Granath F, Petersson G, Harlow B. The influence of gestational age and smoking habits on the risk of subsequent preterm deliveries. N Engl J Med 1999;341:943-8.

130. Berkowitz GS, Blackmore-Prince C, Lapinski RH, Savitz DA. Risk factors for preterm birth subtypes. Epidemiology 1998;9:279-85.

131. Ancel PY, Saurel-Cubizolles MJ, Di Renzo GC, et al; the Europop Group. Social differences of very preterm birth in Europe: interaction with obstetric history. Am J Epidemiol 1999;149:908-15.

132. Williams M, Mittendorf A, Stubblefield P, et al. Cigarettes, coffee and preterm premature rupture of the membranes. Am J Epidemiol 1992;135:895-903.

133. Hadley C, Main D, Gabbe S. Risk factors for preterm premature rupture of the fetal membranes. Am J Perinatol 1990;7: 374-9.

134. Lee T, Silver H. Etiology and epidemiology of preterm premature rupture of the membranes. Clin Perinatol 2001;28:7214.

135. Hoffmann DR, Romero R, Johnston JM. Detection of platelet-activating factor in amniotic fluid of complicated pregnan- cies. Am J Obstet Gynaecol 1990;162:5258.

136. Li CQ, Windsor RA, Perkins L, et al. The impact on infant birth weight and gestational age of cotinine-validated smoking reduction during pregnancy. JAMA 1998;269:1519-24.

137. McCowan LM, Dekker GA, Chan E, et al. Spontaneous preterm birth and small for gestational age infants in women who stop smoking early in pregnancy: prospective cohort study. BMJ 2009;338: b1081.

138. Windham GC, Hopkins B, Fenster L, Swan S. Prenatal active or passive tobacco smoke exposure and the risk of preterm delivery or low birth weight. Epidemiology 2000;11:427-33.

139. Horta BL, Victora CG, Menezes AM, et al. Low birth weight, preterm births and intrauterine growth retardation in relation to maternal smoking. Paediatr Perinat Epidemiol 1997;11:140-1.

140. Petridou E, Salvanos H, Skalkidou A, et al. Are there common triggers of preterm deliveries? $\mathrm{Br} \mathrm{J}$ Obstet Gynaecol 2001;108:598-604.

141. Bennett VR, Brown LK. Myles Textbook for Midwives. 11th ed. Edinburgh, London, Melbourne and New York: Churchill Livingstone; 1989.

142. Froen JF, Arnestad M, Frey K, et al. Risk factors for sudden intrauterine unexplained death: Epidemiologic characteristics of singleton cases in Oslo, Norway, 1986-1995. Am J Obstet Gynaecol 2001; 184:694-702.

143. Royal College of Physicians. Nicotine addiction in Britain. London: Pitman Medical and Scientific Publishing; 2000.

144. Candy D, Davies EG, Ross E. Clinical paediatrics and child health. 1st ed. Philadelphia: WB Saunders; 2001. pp. 15.

145. Kleinman J, Pierre MJ, Madans J, et al. The effects of maternal smoking on fetal and infantmortality. Am J Epidemiol 1988;127:274-82.

146. Malloy MH, Kleinman JC, Land GH, Schramm WF. The association of maternal smoking with age and cause of neonatal death. Am J Epidemiol 1990; 128:46-55.

147. Meyer MB, Tonascia JA. Maternal smoking, pregnancy complications and perinatal mortality. Am J Obstet Gynaecol 1977;128:494-502.

148. Wisborg K, Kesmodel V, Hendriksen TB, et al. Exposure to tobacco smoke in utero and the risk of stillbirth and death in the first year of life. Am J Epidemiol 2001; 154:322-7.

149. Hogberg L, Cnattingius S. The influence of maternal smoking habits on the risk of subsequent stillbirth: is there a causal 
relation? Br J Obstet Gynaecol 2007;114: 699-704.

150. US Department of Health and Human Services $\mathrm{x}$ Women and Smoking. A Report of the Surgeon General. US Department of Health and Human Services, Public Health Service, Office of the Surgeon General, Rockville, MD, USA, 2001.

151. American Academy of Pediatrics Task Force on Sudden Infant Death Syndrome. The changing concepts of sudden infant death syndrome: diagnostic coding shifts, controversies regarding sleeping environment and new variables to consider reducing risk. Pediatrics 2005;116: 1245-55.

152. Browne CA, Colditz PB, Dunster KR. Infant autonomic function is altered by maternal smoking during pregnancy. Early Hum Dev 2000;59:209-18.

153. Dombrowski SC, Martin RP, Huttunen M0. Gestational exposure to cigarette smoke imperils the long-term physical and mental health of offspring. Birth Defects Res A Clin Mol Teratol 2005;73: 170-6.

154. Batstra L, Hadders-Algra M, Neeleman J. Effect of antenatal exposure to maternal smoking on behavioral problems and academic achievement in childhood: prospective evidence from a Dutch birth cohort. Early Hum Dev 2003;75:21-3.

155. Mortensen EL, Michaelsen KF, Sanders SA, Reinisch JM. A dose-response relationship between maternal smoking during late pregnancy and adult intelligence in male offspring. Paediatr Perinat Epidemiol 2005;19:4-11.

156. Lambe M, Hultman C, Torrang A, et al. Maternal smoking during pregnancy and school performance at age 15 . Epidemiology 2006;17:524-30.

157. Cornelius MD, Ryan CM, Day NL, et al. Prenatal tobacco effects on neuropsychological outcomes among preadolescents. J Dev Behav Pediatr 2001;22:217-25.

158. Law KL, Stroud LR, LaGasse LL, et al. Smoking during pregnancy and newborn neurobehavior. Pediatrics 2003;111: 1318-23.

159- Levin ED, Slotkin TA. Developmental neurotoxicity of nicotine. In: W Slikker, LW Chang (eds.) Handbook of developmental neurotoxicity. Academic Press; 1998. pp. 587-615.

160. Slotkin TA. Fetal nicotine or cocaine exposure: Which one is worse? J Pharmacol Exp Ther 1998;285:931-5.

161. Nau H, Hansen R, Steldinger R. Extent of nicotine and cotinine transfer to the human fetus, placenta and amniotic fluid of smoking mothers. Dev Pharmacol Ther 1985;8:384-5.
162. Thilo EH, Rosenberg AA. Tobacco smoking. In: WW Hay, et al. (eds.) Current pediatric diagnosis and treatment. 15th ed. New York: McGraw-Hill; 2001. pp. 20.

163. Suarez L, Ramadhani T, Felkner M, et al. Maternal smoking, passive tobacco smoke, and neural tube defects. Birth Defects Res A Clin Mol Teratol 2011;91: 29-33.

164. Roza SJ, Verhulst FC, Jaddoe VW, et al. Maternal smoking during pregnancy and child behaviour problems: the Generation R Study. Int J Epidemiol 2009;38: 680-9.

165. Braun JM, Froehlich TE, Daniels JL, et al. Association of environmental toxicants and conduct disorder in U.S. children: NHANES 2001-2004. Envir Health Perspect 2008;116:956-62.

166. Rückinger S, Rzehak P, Chen CM, et al. Prenatal and postnatal tobacco exposure and behavioral problems in 10-year-old children: results from the GINI-plus prospective birth cohort study. Envir Health Perspect 2010;118:150-4.

167. US Department of Health and Human Services. The health consequences of involuntary smoking. DHHS (PHS) 878398. USGPO, Washington, DC, USA, 1984.

168. US Environmental Protection Agency. Respiratory health effects of passive smoking: Lung cancer and other disorders. Publication EPA/600/6-0/006F. US Environmental Protection Agency, Office of Air and Radiation, Washington, DC, USA, 1992.

169. Fielding JE, Phenow KJ. Health effects of involuntary smoking. N Engl J Med 1988;319:1452-60.

170. Goel P, Radotra A, Singh I, et al. Effects of passive smoking on outcome in pregnancy. J Postgrad Med 2004;50:12-6.

171- Misra DP, Nguyen RH. Environmental tobacco smoke and low birth-weight: a hazard in the workplace? Envir Health Perspect 1999;107:897-904.

172- Lindbohm ML, Sallmen M, Taskinen H. Effects of exposure to environmental tobacco smoke on reproductive health. Scand J Work Envir Health 2002;28:84-6.

173. Deshmukh JS, Motghare DD, Zodpey SP, Wadhva SK. Low birth weight and associated maternal factors in an urban area. Indian Pediatr 1998;35:33-6.

174. Leonardi-Bee J, Smyth A, Britton J, Coleman T. Environmental tobacco smoke and fetal health: systematic review and meta-analysis. Arch Dis Child Fetal Neonatal Ed 2008;93:F351-61.

175. Cevantes RB, Stringer JR, Shao C, et al. Embryonic stem cells and somatic cells differ in mutation frequency and type. Proc Natl Acad Sci U S A 2002;99:3586-
90.

176. Grant SG. Qualitatively and quantitatively similar effects of active and passive maternal tobacco smoke exposure on in utero mutagenesis at the HPRT locus. BMC Pediatr 2005;5:20-5.

177. Grant SG. Tobacco smoke exposure and somatic mutation in newborns. Open Pediatr Med J 2010;4:10-3.

178. Sasaki S, Kondo T, Sata F, et al. Maternal smoking during pregnancy and genetic polymorphisms in the $\mathrm{Ah}$ receptor, CYP1Aland GSTM1 affect infant birth size in Japanese subjects. Mol Hum Reprod 2006;12:77-83.

179. Grazuleviciene R, Danileviciute A, Nadisauskiene $\mathrm{R}$, Vencloviene $\mathrm{J}$ Maternal smoking, GSTM1 and GSTT1 polymorphism and susceptibility to adverse pregnancy outcomes. Int J Envir Res Public Health 2009;6:1282-7.

180. Stick SM, Burton PR, Gurrin L, et al. Effects of maternal smoking during pregnancy and a family history of asthma on respiratory function in newborn infants. Lancet 1996;348:1060-4.

181. Lødrup Carlsen KC, Jaakkola JJ, Nafstad P, Carlsen KH. In utero exposure to cigarette smoking influences lung function at birth. Eur Respir J 1997;10:1774-9.

182. Hoo AF, Henschen M, Dezateux C, et al. Respiratory function among preterm infants whose mother smoked during pregnancy. Am J Respir Crit Care Med 1998;158:700-5.

183. Milner AD, Marsh MJ, Ingram DM, et al. Effects of smoking in pregnancy and neonatal lung function. Arch Dis Child Fetal Neonatal Ed 1999;80:F8-14.

184. Hanrahan JP, Tager IB, Segal MR, et al. The effect of maternal smoking during pregnancy on early infant lung function. Am Rev Respir Dis 1992;145:1129-35.

185. Young S, Le Souef PN, Geelhoed GC, et al. The influence of a family history of asthma and parental smoking on airway responsiveness in early infancy. $\mathrm{N}$ Engl J Med 1991;324:1168-74.

186. Asmussen I. Fetal cardiovascular system as influenced by maternal smoking.

Clin Cardiol 1979;2:246-56.

187. Holt PG, Keast D. Environmentally induced changes in immunological

function: acute and chronic effects of inhalation of tobacco smoke and other

atmospheric contaminants in man and experimental animals. Bact Rev 1977;41:205-6.

188. Alati R, Al Mamun A, O'Callaghan M, et al. In utero and postnatal maternal smoking and asthma in adolescence. Epidemiology 2006;17:138-44.

189. Jaakkola JJ, Kosheleva AA, Katsnelson BA, et al. Prenatal and postnatal tobacco smoke exposure and respiratory health 
in Russian children. Respir Res 2006; 7:48-54.

190. Bisgaard H, Dalgaard P, Nyboe J. Risk factors for wheezing during infancy. Acta Paediatr Scand 1987;76:719-26.

191. Steffensen FH, Sorensen HT, Gillman MW, et al. Low birth weight and preterm delivery as risk factors for asthma and atopic dermatitis in young adult males. Epidemiology 2000;11:185-98.

192. Infante-Rivard C, Gautrin D, Malo JL, Suissa S. Maternal smoking and childhood asthma. Am J Epidemiol 1999;150: 528-31.

193. Gilliland FD, Li YF, Peters JM. Effects of maternal smoking during pregnancy and environmental tobacco smoke on asthma and wheezing in children. Am J Respir
Crit Care Med 2001;163:429-36.

194. London SJ, James Gauderman W, Avol E, et al. Family history and the risk of earlyonset persistent, early-onset transient, and lateonset asthma. Epidemiology 2001;12:577-83.

195. Strachan DP, Cook DG. Parental smoking and childhood asthma: longitudinal and case-control studies. Thorax 1998;53: 204-12.

196. Jaakkola JJ, Jaakkola MS. Effects of environmental tobacco smoke on the respiratory health of children. Scand J Work Environ Health 2002;28:71-3.

197. Nafstad P, Kongerud J, Botten G, et al. The role of passive smoking in the development of bronchial obstruction during the first 2 years of life. Epidemiology
1997;8:293-7.

198. Gold DR, Burge HA, Carey V, et al. Predictors of repeated wheeze in the first year of life: the relative roles of cockroach, birth weight, acute lower respiratory illness, and maternal smoking. Am J Respir Crit Care Med 1999;160:22736.

199. Håberg SE, Bentdal YE, London SJ, et al. Pre- and Postnatal Parental Smoking and Acute Otitis Media in Early Childhood. Acta Paediatr 2010;99: 99-105.

200. Mukhopadhyay P, Horn KH, Greene RM, Pisano MM. Prenatal exposure to environmental tobacco smoke Alters gene expression in the developing murine Hippocampus. Reprod Toxicol 2010;29: 164-75. 